\title{
Professor Emérito Luiz Eulálio de Bueno Vidigal*.
}

\author{
Celso Neves \\ Professor Thtular de Direito Processual Civil \\ na Faculdade de Direito da Universidade. \\ de São Paulo.
}

Reune-se a Congregação da Faculdade de Direito da Universidade de São Paulo, para outorga solene, em sessão pública, do título de Professor Emérito a LuIz Eulálio DE Bueno Vidigal. A mim - seu sucessor na titularidade da Cadeira de Direito Processual Civil que tanto ilustrou cabe-me a honra insigne e a alegria imensa de saudá-lo, neste momento que assinala a consagração maior de tôdas as suas vitórias, no magistério superior da terra em que nasceu. Honra insigne é isso, para mim, pela altitude da representação que implica; alegria imensa, pela oportunidade de estar à porta, para o abraço comovido e fraterno, na hora do seu retôrno triunfal a esta Casa, em que teve o privilégio de ver realizados os seus sonhos de adolescente e a sua vocação de mestre de Direito.

Antes, para aqui entrar, três vezes bateu êle a aldrava envelhecida do portal nobre dêste monastério.

A primeira vez, ainda no verdor de seus dezessete anos - quando as taipas sagradas delimitavam o átrio, o cláustro e os demais capítulos da velha Academia de Direito de São Paulo, impondo ao Largo de São Francisco

*. Discurso proferido na sessão solene da Congregação, realizada aos 8 de março de 1973, para a outorga do título de professor emérito ac Dr. Luiz Eulalio de Bueno Vidigal. 
o sabor de gravura antiga, a que não faltava o destaque colonial da Igreja que até hoje permanece e ainda abriga a fraternidade venerável da antiga Província Franciscana de Santo Antonio do Brasil. Era para o vestibular - que lhe abriria o caminho de sua formação jurídica, ao tempo em que foi Diretor Antonio Januário Pinto Ferraz, "fino, elegante, irônico, exemplar de cavalheiro do século 19", como, mais tarde, viria a descrevê-lo.

A segunda vez em que aqui bateu, o sítio era o mesmo, mas outra era a feição da casa, tal qual hoje nos abriga, e a primeira turma universitária - a de 1939, a que me honro de pertencer - a 16 de janeiro, do ano seguinte, colara grau. Foi isso, pois, em 1940, para um primeiro e brilhante concurso que a êle abriu, como livredocente, o caminho do doutoral que tanto o deslumbrara quando, já acadêmico, pela primeira vez o havia defrontado.

A terceira vez, treze anos depois, ao conquistar, em novo e memorável concurso, as galas da Cátedra de Direito Judiciário Civil, vaga com o falecimento daquele eminente e bondoso Sebastiano Soares de Faria, meu paraninfo de 1939. Realizava-se, assim, o sonho docemente acalentado quando ainda ginasiano, antes mesmo "de vir a conhecer a Faculdade de Direito em todo o brilho de suas tradições centenárias", como diria em seu discurso de posse, depois da saudação de Theotonio Monteiro de Barros Filho, êsse talento excepcional que, para nosso desalento, tão cêdo se desvanece.

Dez anos depois, era a Congregação que, sensibilizada pela obra de professor eminente que sempre caracterizou o magistério de LuIz Eulálio de Bueno Vidigal, o indicava, em lista tríplice, para Diretor, cargo a que foi alçado pela escolha do então e Magnífico Reitor Luiz ANTônio da Gama E Silva, também professor desta Casa que em Junho de 1953 o antecedera no doutoral, ilustrando a Cátedra de Direito Internacional Público. 
Na Diretoria, realizou uma administração marcante que a nenhum de nós surpreendeu, porque os vinte e três anos de magistério até então vencidos não permitiam dú.. vida sôbre a firmeza do seu pulso timoneiro e a orientação escorreita que imprimiria às altas atribuições de que fôra investido. Vigoroso e preciso nas decisões, a obra então realizada assinalou nova e merecida consagração.

Cumprido o mandato de Diretor, permanece na Cátedra, sempre fiel ao credo que professara, ao assumi-la:

"A assiduidade, se não fôsse dever funcional do professor, deveria ser ostentada como um galardão e não evitada como um indício de mediania; as leituras e preleções sempre renovadas, se não correspondessem a uma exigência indeclinável de qualquer intelectual, seriam evidência de inquietação salutar de espírito e, de forma alguma, "desrespeito à tradição e amor incondicional da novidade; o rigor no julgamento dos exames, se não constituisse pressuposto inseparável dos privilégios que o diploma confere, seria o maior benefício que pode o professor dispensar aos seus alunos e não a maldosa preocupação de embaraçá-los nos primeiros passos de sua vida."

Dêstes — que fazem o corpo discente da Academia dera expressivo testemunho, ao empossar-se Diretor:

"Não consigo, sem embargo da atoarda continua das cassandras da educação nacional, convencer-me da propalada decadência moral e intelectual de nossa juventude. Em tôdas as minhas turmas encontrei numerosos alunos dedicados aos estudos, inteligentes, cultos e sérios. Entre os muitos que não ostentam êsses atributos nunca encontrei insolentes, pérfidos, indisciplinados." 
Depois da aposentadoria voluntária, não tardou que o fôssem buscar, para a permanência no Curso de PósGraduação e a Chefia do Departamento de Processo caminho imediato de regresso pleno à Congregação.

Agora, a suma distinção - que só se concede, após o afastamento da Cátedra, aos que, ao ensino, tenham prestado serviços de excepcional relevância: Professor Emérito!

Do merecimento com que recebe o título dignificante, diz alto a sua obra. Da Execução Direta das Obrigações de Prestar Declaração de Vontade foi a monografia que o levou a Livre-Docente. Como acentuou êsse mestre consumado que é Alfredo Buzaid, vinha ela "rasgar novos horjzontes nos domínios da execução específica, que o Código de Processo Civil, sancionado em 1939, ensaiava entre nós como fórmula de tutela jurídica". Da Ação Rescisória dos Julgados vem a lume em 1948, situando-se entre as obras clássicas da nossa literatura jurídica sôbre a intrincada matéria. Da Imutabilidade dos Julgados que Concedem Mandado de Segurança é tese com a qual, em 1953, conquista a Cátedra, sustentando posição original, desenvolvida em têrmos rigorosamente científicos.

As duas monografias de concurso e mais uma série de estudos diversos, de altíssima expressão, reune-os, em 1965, no Direito Processual Civil. Mas a obra principal, essa ainda não foi editada e resulta dos cursos que ministrou nesta Faculdade, com aquela segurança e coerência de quem domina a matéria, fonte de ensinamentos preciosos, infelizmente de difícil acesso, porque enclausurada na cela estreita das postilas.

Tendo em supremo aprêço a sua estatura de jurista e de educador foi que, em meu discurso de posse na titularidade da Cadeira de Direito Processual Civil, referindo-me ao mestre a que sucedia, confessei: "Jamais tive a veleidade de substituí-lo na regência da cadeira que tanto dignificou e da qual se afasta na plenitude do seu 
saber e de sua jovialíssima maturidade. O que nele mais impressiona é a sua independência total. Jurista que pensa os problemas da nossa ciência, para dar-lhes soluções originais, marcantemente suas, é bem um exemplo de emancipação intelectual, firme nas suas concepções, rigorosamente lógico nos seus raciocínios, livre, seguro e profundamente fecundo nas suas construções, a que não falta $o$ módulo do maior rigor científico e do mais adequado senso pragmático."

Não surpreendem, pois, as raizes fartas e vigorosas do seu proselitismo, de que provém uma larga floração de discípulos, encantados pelas lições do Mestre.

Tendo a bom conselho a advertência de São Paulo apóstolo a Timóteo, persevera nas cousas que apreendeu e de que tem certeza, "insta, a tempo e fora de tempo, convence, repreende, exorta com tôda a paciência e ensino". Assim realiza os seus sonhos de juventude e ilustra os fastos desta Academia, fiel às suas tradições e cuidadoso do seu futuro, sem ousar uma adesão solene ao voto de que "o mais antigo dos institutos universitários de São Paulo, pudesse levar intacto, dêste glorioso Largo de São Francisco para a esplêndida Cidade Universitária, todo nosso patrimônio de glórias e tradições". Quero apenas - disse, quando isso confessou - "nesta hora de exaltação e de alegria, exprimir o desejo de que a nossa Faculdade encontre sempre na sabedoria de seus mestres, na operosidade de seus funcionários, na diligência de seus alunos, e no patriotismo de todos, a justa medida de compromisso entre as nobres exigências da tradição acadêmica e os impulsos incoercíveis da renovação e do progresso."

Eis aí, no rápido bosquejo de leve impressionismo, a síntese de uma grande vida - que dignifica sua nobre ascendência, engrandece a sua terra e a sua gente, envaidece a sua descendência e sensibiliza, profundamente, o círculo afetivo de tantos e devotados amigos que se comprazem com suas vitórias. 
Professor Emérito Luiz Eulälio de Bueno Vidigal: a Congregação aqui reunida, orgulha-se, principalmente, dessa vida, já incorporada, com galas excepcionais, às memórias mais próximas e ao presente austero da velha Academia do Largo de São Francisco e vos recebe, nesta solenidade, entre os seus mais altos valores, com transbordante emoção e redobrada alegria. Cingí, pois, as vestes de triunfador e entrai no gôzo das prerrogativas de que sois investido.

\section{Discurso do homenageado.}

Ouví, há quarenta anos, de um velho professor que, juntamente com o grau de bacharel que nos deu, dirigiu a minha turma os conselhos e as despedidas dos mestres, palavras que, mais do que a jovens causidicos se destinavam a futuros lentes. "Há professores indignos? Podem puní-los os próprios alunos mediante a opção pelos cursos dos livres docentes." "Existem alguns que se enquistam em suas cadeiras e, agarrados a elas, permanecem durante trinta, quarenta, cinquenta anos, atravancando a disciplina, prejudicando gerações sobre gerações de estudantes, impedindo a renovação do professorado? Cumpra-se a lei : sejam eles aposentados compulsoriamente". Não esperei pela punição dos alunos nem pela sanção legal ao crime de sobrevivência. Preferi abrir eu mesmo as portas aos valorosos docentes livres da escola, para que êles, com o saber que já demonstraram e o entusiasmo que ainda se não desgastou, assumissem o encargo de transmitir ao novos a cultura das gerações anteriores.

Muitas e muitas vezes já destes a outros mestres o título com que hoje me galardoais. A variedade dos temperamentos dos que o receberam determinou a diversidade das respectivas reações. $O$ grande número nêle se investiu com orgulho e desvanecimento. Uns poucos, com humildade. Menos ainda, com desdem a indiferença. De mim, 
atento ao significado primeiro da palavra, exausto, acabado, se não me posso inflar de vaidade, certamente não me posso conter de alegria e reconhecimento. E que esta escola não abandona seus filhos e dêles não se esquece. Acolhe-os ainda uma vez para honrá-los na solenidade da despedida. E para poupar-lhes, o inevitavel sentimento de frustração e inutilidade, piedosamente finge corresponder o título a prêmio por serviços de excepcional relevância prestados ao magistério e promete conclamá-los para realizarem cursos livres e fazerem parte de comissões universitárias.

Não é a primeira vez que a escola doce e suavemente me constrange a voltar ao convivio que voluntariamente deixei. $\mathrm{Na}$ primeira, trouxe-me Alfredo Buzaid, mestre da ciência e da amizade, contratando-me para ensinar, no Curso de Especialização, Teoria Geral do Processo Civil. Depois, Joaquim Canuto, espírito original e carater desprendido, que me cedeu o lugar, que era seu por todos os títulos, na chefia do Departamento de Direito Processual, e teve a iniciativa da proposta desta homenagem. Finalmente, Pinto Antunes, artista e mestre, sempre enamorado da escola, que, pela palavra de Celso Neves, aqui me trouxe para esta gloriosa investidura.

Ao tomar posse, há vinte anos, da cátedra, que, sob outra denominação, hoje é brilhantemente regida por Celso Neves, esse mestre de direito e de ética profissional, defendi, em curta profissão de fé, a assiduidade, a renovação das preleções e o rigor no julgamento dos exames. No exercício da cátedra, desencantei-me das duas últimas. Fui professor assiduo. Não renovei, porém, minhas preleções nem fui tão rigoroso quanto pretendia. Convencí-me, na prática do magistério, de que o professor deve ensinar pouco e bem. Sòmente depois de alguns anos de experiência, percebe que a extensão, e mesmo a profundeza, hão de ceder o passo à firmeza das noções fundamentais. De 
outro lado, senti que deve ser mantido certo equilibrio entre as numerosas matérias do curso e entre os esforços que se exigem das sucessivas gerações de estudantes. A experiência mostra que não são os professores mais rigorosos - e certamente também não os mais brandos - que criam verdadeiras escolas.

Tenho a satisfação de aqui deixar, ensinando, cerca de uma dezena de discípulos meus. $\mathrm{E}$ entre aqueles que eu não ousaria chamar de meus discípulos, mas foram meus alunos; conto nada menos do que cinco professores catedráticos. Peço permissão para salientar dois: Manoel Gonçalves Ferreira Filho entre os mais novos e, entre os mais antigos, Oscar Barreto Filho, que ouviu a primeira preleção que aqui proferí, e que nos dará dentro em pouco a preleção inaugural do ano letivo. $\mathrm{E}$ já que é próprio da solenidade evocar os mestres, os discípulos e os amigos, menciono afinal, em preito de gratidão, o mestre Jorge Americano que, em minha saudade, simboliza tudo quanto minha querida Faculdade tem de grande, belo e cavalheiresco. 